\title{
Beyond Binder: Determination of Criminal Responsibility while in a State of Drunkenness by Japanese Courts
}

\author{
Akihiro Shiina $^{1,2 *}$, Mihisa Fujisaki and Masaomi lyo $0^{1,2,3}$
}

${ }^{1}$ Department of Child Psychiatry, Chiba University Hospital, Inohana 1-8-1, Chuoh-ku, Chiba-shi, Chiba, Japan

${ }^{2}$ Center for Forensic Mental Health, Chiba University, Japan

${ }^{3}$ Division of Psychiatry, Graduate School of Medicine, Chiba University, Japan

\begin{abstract}
In Japan, unlike many other countries, forensic psychiatry has traditionally used Binder's criterion for determining the criminal responsibility of drunken offenders. We investigated 50 judgment documents taken from District courts and analyzed them for the implementation of Binder's criterion and other factors, to determine criminal responsibility. Only 20 documents explicitly mentioned Binder's criterion. Decisions were based not only on Binder's criterion, but also additional factors related to the crime, which could contribute to diminished responsibility. Logistic regression analysis showed that decisions of diminished criminal responsibility were related to factors such as, "memory loss", "incomprehensible motive", and "heterogeneous character of the perpetrator". These results suggest that Japanese District courts do not adhere as strictly to Binder's criterion as originally thought by Japanese forensic psychiatrists. The courts also use what would be deemed "common sense standards" when determining criminal responsibility.
\end{abstract}

Keywords: Forensic mental health; Criminal responsibility; Drunkenness; Intoxication; Binder's criterion; Judgment documents; Observational study

\section{Background}

Judging the criminal responsibility of perpetrators while in a state of drunkenness is an important issue for both public security policy and forensic mental health. The policies on how to deal with drunken offenders differ from country to country.

The current legal position in many countries such as Canada [1], The Netherlands [2] and United States of America [3], is for offenders, in principle, to take full responsibility for criminal acts performed while under the influence of alcohol. In Germany, attempts are made to determine criminal responsibility, based on the level of alcohol present in the blood of offenders, at the time of the offence [1]. In Japan, it was thought that courts relied on Binder's criterion for determining the degree of responsibility of offenders, as part of their judgment [4].

Through clinical observations, Binder classified the state of drunkenness into three categories denoted as simple drunkenness, complex drunkenness, and pathological drunkenness [5]. In his definition, simple drunkenness is a normal reaction to the rapid intake of alcohol. In this state, subjects display feelings of happiness and elevated mood, with minimal disinhibition, and normal psychomotor function and orientation. No delusions, hallucinations or character changes are present. In complex drunkenness, subjects feel irritation and disinhibition, often with rapidly progressive changes of emotion or severe changes in character. However, throughout this, the observed behavior is easily comprehensible and orientation is intact. Sometimes delusional thoughts appear but hallucinations are rare. In addition, partial memory lapses occur. In pathological drunkenness, subjects show extreme excitement and disturbances of consciousness. Their underlying mood is marked by anxiety and orientation is disturbed.

Binder claimed that simple, complex and pathological drunkenness correspond to states of full responsibility, diminished responsibility, and irresponsibility, respectively [4]. He developed this criterion to assist courts in determining the criminal responsibility of drunken offenders. However, his criterion has also been criticized [6].
Both ICD-10 and DSM-IV define drunkenness as acute intoxication with alcohol, in which complications such as delirium are specified. This differs from Binder's three-category classification. Unlike Binder, neither ICD-10 nor DSM-IV distinguishes between complex and simple drunkenness. ICD-10 simply states that increasing alcohol intake often causes agitation or aggression. Idiosyncratic alcohol intoxication, resulting in disturbances of consciousness with little drinking, is described in ICD-10 as pathological intoxication, similar to Binder's pathological drunkenness, however, this state is not recognized in DSM-IV [3,7].

Moreover, Binder's criterion is rarely accepted in the context of social justice, except in China [8]. Binder insisted that inappropriate acts, different from one's normal behavior, often appear in complex drunkenness, and that these acts are those of "problem-drinkers". It is generally difficult to accept the idea that "problem drinkers" need only accept diminished responsibility for their actions.

Currently, most Japanese forensic psychiatrists still refer to Binder's criterion in professional practice while acknowledging that courts in Japan are less likely to accept this criterion. This dichotomy in practice could pose problems for the consistent treatment of intoxicated offenders within the Japanese criminal justice system. In addition, courts in most other countries do not accept Binder's criterion [4,9]. These factors currently fuel a push for researchers to devise a new and hopefully unifying standard for determining the state of drunkenness within legal contexts [10].

*Corresponding author: Akihiro Shiina, MD, PhD, Department of Child Psychiatry Chiba University Hospital, Inohana 1-8-1, Chuoh-ku, Chiba-shi, Chiba, Japan, Tel: +81-43-226-2297; Fax: +81-43-226-2297; E-mail: shiina-akihiro@faculty.chiba-u.jp

Received November 26, 2012; Accepted December 29, 2012; Published December 31, 2012

Citation: Shiina A, Fujisaki M, lyo M (2013) Beyond Binder: Determination of Criminal Responsibility while in a State of Drunkenness by Japanese Courts. Forensic Res S11: 005. doi:10.4172/2157-7145.S11-005

Copyright: (C) 2013 Shiina A, et al. This is an open-access article distributed unde the terms of the Creative Commons Attribution License, which permits unrestricted use, distribution, and reproduction in any medium, provided the original author and source are credited. 
In this study, we aimed to examine whether Binder's criterion was still accepted for determining criminal responsibility in Japanese distinct courts, through the investigation of judgment documents relating to criminal trials.

\section{Materials and Methods}

We chose the electronic TKC legal information database, one of the largest legal databases in Japan, as a source of material for this study. From this database, we selected all judgment documents from Japanese courts that included both the search terms 'Meitei' (drunkenness) and 'Sekinin-Nouryoku' (criminal responsibility).

First, we read court papers in their entirety, and noted all contents describing both the use of Binder's criterion and the category of drunkenness (simple, complex or pathological) used in the judgment, to ascertain criminal responsibility.

Next, we noted any descriptions of blood alcohol contents of offenders. We also noted any descriptions of additional factors that could affect criminal responsibility, including; 'consciousness (alert or disturbed)', 'orientation (well-oriented or disoriented)', 'memory of the crime (full memory, partial memory or completely lapsed memory)', 'mood (normal or disrupted)' and 'psychotic symptoms (none or the presence of hallucinations and/or delusions). These factors are deemed important for the assessment of mental state and degree of drunkenness of offenders. We also documented factors relating to, 'the motive for the crime (understandable or incomprehensible)', 'planning of the crime (well planned or impulsive)', 'character heterogeneity of the offender at the time of the crime (similar or heterogeneous compared with the usual character of the offender)', and 'rationality of the crime process (rational or irrational)', all of which are considered 'common sense standards' for the decision of criminal responsibility.

\section{Results}

We initially identified a total of 133 documents from the years 1954 to 2008. Of which, 83 documents were excluded for a number of reasons ( 8 cases from civil trials, 10 cases in which the offender was not drunk, 2 cases in which the subject was found not guilty due to an lack of evidence, 6 cases where criminal responsibility was not mentioned or not mentioned in relation to drunkenness, 49 cases from the High court, 7 cases from the Supreme court and 1 case of unknown detail). We analyzed the remaining 50 documents for this study.

Cases classified according to crime were; 21 murders, 2 attempted murders, 5 incidents of injury or injury causing death, 4 sex offences, 5 robberies or attempted robbery, 5 arson attacks and 8 'others'. Classification according to criminal responsibility was as follows; 5 not guilty by reason of insanity (irresponsibility), 12 guilty with diminished responsibility, and 33 guilty with full responsibility. Punishment in guilty cases was categorized as follows; 3 were sentenced to death, 6 were sentenced to imprisonment with work, for an unlimited term, 33 were sentenced to imprisonment with work, for a defined time, in which the average term is 68.3 months, and 3 were sentenced to suspended imprisonment with work. Blood alcohol levels at the time of the crime were recorded in only 12 cases.

Only 20 papers mentioned Binder's criterion, spanning a period from 1959 to 2008, in which there were 10 classifications of simple drunkenness, 7 of complex drunkenness, and 3 of pathological drunkenness. Table 1 shows the correlation between the category of Binder's criterion and criminal responsibility. On this occasion, the number of cases was not adequate for quantitative evaluation.
Next, we examined the correlation of factors other than Binder's criterion, used to assess diminished criminal responsibility. Odds ratios are shown in Table 2. According to our findings, certain medical and behavioral factors correlated to criminal responsibility, in particular, incomprehensible motivation and the heterogeneous character of the criminal. However, the interaction of these factors could not be analyzed, due to the large number of null data, resulting in a small sample size.

Finally, we applied regression analysis to our data, with the aim of assessing criminal responsibility without applying Binder's criterion. We set diminished responsibility as the dependent variable, and the nine factors of; disturbed consciousness, disorientation, memory loss, abnormal mood, psychotic symptoms, incomprehensible motive, impulsive crime, heterogeneous character of the criminal, and irrational criminal process, as independent variables. We used stepwise, logistic regression analysis, with increasing variables. This result is shown in Table 3 . Three variables were extracted, namely, memory loss, incomprehensible motive, and heterogeneous character of the criminal. The regression formula was calculated as follows; log $(\mathrm{P} /[1-\mathrm{P}])=2.366^{*}$ (Memory Loss $)+4.074^{*}$ (Incomprehensible motive) $+4.131^{\star}$ ( Heterogeneous character of the criminal) -3.291 .

\section{Discussion}

We investigated judgment decision documents from Japanese district courts, for the purpose of evaluating the usage of Binder's criterion to assess criminal responsibility of drunken offenders. Of the

\begin{tabular}{|l|c|c|c|c|}
\hline $\begin{array}{l}\text { Criminal } \\
\text { Responsibility }\end{array}$ & $\begin{array}{c}\text { Full } \\
\text { Responsibility }\end{array}$ & $\begin{array}{c}\text { Diminished } \\
\text { Responsibility }\end{array}$ & $\begin{array}{c}\text { Not Guilty by } \\
\text { Reason of } \\
\text { Insanity }\end{array}$ & Total \\
\hline $\begin{array}{l}\text { Simple } \\
\text { Drunkenness }\end{array}$ & 9 & 1 & 0 & 10 \\
\hline $\begin{array}{l}\text { Complex } \\
\text { Drunkenness }\end{array}$ & 1 & 6 & 0 & 7 \\
\hline $\begin{array}{l}\text { Pathological } \\
\text { Drunkenness }\end{array}$ & 0 & 0 & 3 & 3 \\
\hline $\begin{array}{l}\text { Other or } \\
\text { unspecified }\end{array}$ & 23 & 7 & 0 & 30 \\
\hline
\end{tabular}

Table 1: The correlation between the category of Binder's criterion and crimina responsibility.

\begin{tabular}{|c|c|c|c|}
\hline $\begin{array}{l}\text { Criminal } \\
\text { Responsibility }\end{array}$ & Full & Diminished & Odds Ratio \\
\hline Consciousness & $\begin{array}{c}\text { Clear:12 } \\
\text { Disturbed:0 }\end{array}$ & $\begin{array}{c}\text { Clear:2 } \\
\text { Disturbed:5 }\end{array}$ & N/A \\
\hline Orientation & $\begin{array}{c}\text { Oriented:1 } \\
\text { Disoriented:4 }\end{array}$ & $\begin{array}{c}\text { Oriented:2 } \\
\text { Disorienter:4 }\end{array}$ & 2 \\
\hline Memory & $\begin{array}{l}\text { Maintained:8 } \\
\text { Disordered:17 }\end{array}$ & $\begin{array}{l}\text { Maintained:10 } \\
\text { Disordered:5 }\end{array}$ & 2 \\
\hline Mood & $\begin{array}{l}\text { Not mentioned:0 } \\
\text { Abnormal: } 9\end{array}$ & $\begin{array}{l}\text { Not mentioned:0 } \\
\text { Abnormal: } 4\end{array}$ & N/A \\
\hline Psychotic symptoms & $\begin{array}{l}\text { Absent:6 } \\
\text { Present:2 }\end{array}$ & $\begin{array}{l}\text { Absent:1 } \\
\text { Present:4 }\end{array}$ & 12 \\
\hline Motive for the crime & $\begin{array}{l}\text { Understandable:19 } \\
\text { Incomprehensible:1 }\end{array}$ & $\begin{array}{l}\text { Understandable: } 4 \\
\text { Incomprehensible: } 9\end{array}$ & 43 \\
\hline Planning of the crime & $\begin{array}{l}\text { Well planned:1 } \\
\text { Impulsive:5 }\end{array}$ & $\begin{array}{l}\text { Well planned:3 } \\
\text { Impulsive: } 1\end{array}$ & 15 \\
\hline $\begin{array}{l}\text { Character } \\
\text { homogeneity of the } \\
\text { criminal }\end{array}$ & $\begin{array}{l}\text { Homogenous:7 } \\
\text { Heterogenous:1 }\end{array}$ & $\begin{array}{l}\text { Homogenous: } 1 \\
\text { Heterogenous:10 }\end{array}$ & 70 \\
\hline $\begin{array}{l}\text { Rationality of the } \\
\text { criminal process }\end{array}$ & $\begin{array}{l}\text { Rational:17 } \\
\text { Irrational:2 }\end{array}$ & $\begin{array}{l}\text { Rational:2 } \\
\text { Irrational:6 }\end{array}$ & 26 \\
\hline
\end{tabular}

Table 2: The correlation of factors other than Binder's criterion, used to assess diminished criminal responsibility. 
Citation: Shiina A, Fujisaki M, lyo M (2013) Beyond Binder: Determination of Criminal Responsibility while in a State of Drunkenness by Japanese Courts. J Forensic Res S11: 005. doi:10.4172/2157-7145.S11-005

Page 3 of 3

\begin{tabular}{|l|c|c|c|c|c|}
\hline Variables & B & SE & Wald & P value & Exp(B) \\
\hline Memory Loss & 2.366 & 1.178 & 4.031 & 0.045 & 10.652 \\
\hline Incomprehensible motive & 4.074 & 1.523 & 7.152 & 0.007 & 58.773 \\
\hline Heterogeneous character of the criminal & 4.131 & 1.482 & 7.772 & 0.005 & 62.252 \\
\hline Constant & -3.291 & 1.027 & 10.269 & 0.001 & 0.037 \\
\hline
\end{tabular}

Table 3: Logistic regression analysis, with increasing variables.

fifty analyzed cases, only forty percent of papers explicitly mentioned Binder's criterion.

Hans Binder was a Swiss born psychiatrist who devised a three tier classification of criminal responsibility for subjects under the influence of alcohol. Binder's criterion was introduced to Japan in 1982, [11] and is a widely accepted by older Japanese psychiatrists, probably because of the strong influence of German psychiatry within Japan. However Binder's criterion was not well accepted in Germany.

Our results show that judges in District courts do not rely as heavily on Binder's criterion as originally thought, by Japanese forensic psychiatrists.

A detailed observation of the subject's mental state is essential for utilizing Binder's criterion. An assessment of mental state is referred to in most of the judgment documents. In this study, character heterogeneity of the criminal was strongly related to diminished responsibility. This parameter is also used for evaluating drunkenness in Binder's criterion. However, abnormal mood and disorientation, also factors evaluated by Binder, showed no correlation with diminished responsibility in this cohort. Judges also paid strong attention to the motive for the crime in reaching their decisions on the status of responsibility. Memory loss was considered a causative factor for diminished responsibility. However great care needs to be taken when assessing this factor as many offenders claim a memory lapse irrespective of their level of drunkenness [12].

These findings strongly suggest that Japanese distinct courts do not rely on Binder's criterion to the degree thought by Japanese forensic psychiatrists. Judges assess criminal responsibility based on observed psychiatric symptoms and additional common sense standards, some elements of which overlap with Binder's criterion. It would be highly advantageous for psychiatrists and judges to use the same criteria for evaluating the mental status of offenders. In modern legal practice, it should be possible to evaluate the criminal responsibility of offenders in a state of alcohol intoxication, by conducting detailed analyses of their mental state based on clinical symptoms, and without slavishly applying Binder's criterion [13].

\section{Conclusion}

As with all studies of this nature, the present study has some limitations. In some instances, sample size was not adequate for precise statistical analysis. Also, in Japan, cases where strong doubt exists about criminal responsibility tend not to be prosecuted, which could lead to analytical bias. Additionally, it cannot be guaranteed that all factors considered by judges when making their decisions, have been recorded in case documentation. These points agreed, our research shows that within the legal system, judges make limited use of Binder's criterion when determining the criminal responsibility of drunken offenders.

\section{References}

1. Fischer B, Rehm J (1998) Intoxication, the law and criminal responsibility--a sparkling cocktail at times: the case studies of Canada and Germany. Eur Addict Res 4: 89-101.

2. van Kalmthout $A$ (1998) Intoxication and criminal responsibility in Dutch criminal Law. Eur Addict Res 4: 102-106.

3. Sadock BJ, Sadock VA, Ruiz P (2009) Kaplan and Sadock's Comprehensive Textbook of Psychiatry, (9thedn). Lippincott Williams \& Wilkins.

4. Yamagishio K, Keiji Y, Kimura T, Yamabayashi S, Katsushima H (2009) [Quality of life evaluation in elderly normal tension glaucoma patients using the Japanese version of VFQ-25]. Nihon Ganka Gakkai Zasshi 113: 964-971.

5. Binder H (1935) Über alkoholische Rauschzustände : Sonderdruck, Schweizer Archiv für Neurologie und Psychiatrie.

6. Kondou K. Meitei Bunrui to Sekinin-Nouryoku Binder no 3 Bunsetu no keireki. [Classification of Drunkenness and Criminal Responsibility; History of Binder's Criterion] The Teikyo law review 19: 241-256.

7. Gelder M, Andreasen N (2009) New Oxford Textbook of Psychiatry, (2ndedn) Oxford University Press, United Kingdom.

8. Chugoku YZ (2012) Doli Capax and its judgments under Article 18 of the Chinese Penal Code. Japanese J of Law and Psychiatry 27: 125-144.

9. Takada T, Takaoka T, Kanaoka S (2007) Crimes under the state of drunkenness and criminal responsibility. Jap J Psychiatry 49: 1263-1273.

10. Kageyama J (2001) Psychiatric examination for criminals with alcohol or other drugs. J Jap Med Association 125: 1421-1424.

11. Kageyama J (1982) von Hans Binder Uber alkoholische Rauschzustände Seishinigaku 24: 855-866.

12. van Oorsouw K, Merckelbach H, Ravelli D, Nijman H, Mekking-Pompen I (2004) Alcoholic Blackout for Criminally Relevant Behavior. J Am Acad Psychiatry Law 32: 364-70.

13. Yakubutu MM (1999) Drug \& Alcohol related disorders, Encyclopedia of Clinical Psychiatry, Nakayama shoten. 